\title{
Clinico-Pathologic Factors Affecting Lymph Node Metastases in Cervical Cancer
}

\author{
Serviks Kanserinde Lenf Nodu Metastazına Etki Eden Kliniko-Patolojik Faktörler
}

\author{
Huseyin Akilli, Ali Ayhan \\ Department of Obstetrics and Gynecology, Division of Gynecologic Oncology, Baskent University School of Medicine, Ankara, Turkey
}

\begin{abstract}
Aim: The aim of this study was to define clinico-pathologic factors affecting lymph node metastases in cervical cancer patients.

Material and Method: This retrospective study was carried out in the Gynecologic Oncology Division of Baskent University in Ankara, Turkey. Cervical cancer patients operated on between 2008 and 2019 were analyzed. Patient's demographic and pathologic reports (histology, lymphovascular space invasion [LVSI], stromal invasion, parametrial involvement, lymph node metastases) were documented.
\end{abstract}

Results: A total of 352 cervical cancer patients were included in this study. The median age of the study group was 49 (23-87) years and the median tumor size was $3.2(1-11) \mathrm{cm}$. While 273 (70\%) patients had positive LVSI, 299 (85\%) patients had deep stromal invasion (DSI) of more than $50 \%$ of the cervical stroma. In univariant analyses, DSI, LVSI, and parametrial invasion affected lymph node metastases ( $p=0.006, p=0.000$, and $p=0.000$, respectively). However, in multivariant analyses, LVSI (HR: 32.6 (95\% Cl: 7.8-136.2, $p=0.001$ ) and parametrial invasion (HR: 3.52, 95\% Cl: 1.7-6.9, $p=0.001$ ) remained significant. Five-year overall survival of patients with and without lymph node metastases was $70 \%$ and $85 \%$, respectively $(p=0.001)$.

Conclusion: LVSI and parametrial invasion were found to independently increase the risk of lymph node metastases in cervical cancer patients. For this reason, prospective studies are needed to identify these risk factors preoperatively.

Key words: cervical cancer; lymph node metastases; survival

\section{ÖZET}

Amaç: Bu çalıșmanın amacı, rahim ağzı kanseri hastalarında lenf nodu metastazlarını etkileyen klinikopatolojik faktörleri tanımlamaktır.

Materyal ve Metot: Bu retrospektif çalıșma Ankara'da Bașkent Üniversitesi Jinekolojik Onkoloji Bilim Dalı'nda yapılmıștır. 2008 ile 2019 yılları arasında ameliyat edilen rahim ağzı kanseri hastaları analiz edildi. Hastanın demografik ve patolojik raporları (histoloji, lenfovasküler boșluk invazyonu [LVSI], stromal invazyon, parametrial tutulum, lenf nodu metastazları) belgelendi.
Bulgular: Bu çalıșmaya toplam 352 rahim ağzı kanseri hastası dahil edildi. Çalıșma grubunun ortanca yașı 49 (23-87) yıl ve ortalama tümör boyutu 3,2 (1-11) cm idi. 273 (\%70) hastada pozitif LVSI varken, 299 (\%85) hastada servikal stromanın \%50'sinden fazla derin stromal invazyon (DSI) vardı. Tek değișkenli analizlerde, DSI, LVSI ve parametrial invazyon lenf nodu metastazlarını etkiledi (sırasıyla $p=0,006, p=0,000$ ve $p=0,000$ ). Ancak, çok değișkenli analizlerde, LVSI (HR: 32,6 (\%95 Cl: 7,8-136,2, $p=0,001)$ ve parametrial invazyon (HR: 3,52, \%95 Cl: 1,7-6,9, $p=0,001$ ) anlamlı kaldı. Lenf nodu metastazı olan ve olmayan hastaların genel sağkalımı sırasıyla \%70 ve $\% 85$ idi $(p=0,001)$.

Sonuç: LVSI ve parametrial invazyonun, servikal kanser hastalarında lenf nodu metastazı riskini bağımsız olarak artırdığı bulunmuștur. Bu nedenle ameliyat öncesi bu risk faktörlerinin belirlenmesi için ileriye dönük çalıșmalara ihtiyaç vardır.

Anahtar kelimeler: rahim ağzı kanseri; lenf nodu metastazları; sağ kalma

\section{Introduction}

It is estimated that 13.1 per 100,000 women will be diagnosed with cervical cancer worldwide and eventually 6.9 per 100,000 of them will die. Cervical cancer is the fourth leading cause of cancer-related death among women ${ }^{1}$. Radical surgery and pelvic lymphadenectomy still remain the best treatment options for early-stage cervical cancer $^{2}$. Formerly, cervical cancer staging was based on clinical findings and lymph node metastases did not alter the stage. Lymph node metastasis was considered as a high-risk pathologic factor with positive surgical margins and parametrial invasion.

Finally, this clinico-pathologic dilemma was corrected in 2018 by the Federation of Gynecology and Obstetrics (FIGO) and lymph node metastasis was

IIetișim/Contact: Hüseyin Akull, Baskent University School of Medicine, Department of Obstetrics and Gynecology, Division of Gynecologic Oncology, Ankara, Turkey • Tel: 05057979434 •E-mail:hsynakilli@hotmail.com • Geliș/Received: 26.10.2020 • Kabul/Accepted: 26.12.2020

ORCID: Hüseyin Akill, 0000-0002-5240-8441 • Ali Ayhan, 0000-0001-7155-9096 
revised as stage III even if not pathologically proven and based on imaging ${ }^{3}$. After that revision, validation studies showed the accuracy of the new classification system $^{4,5}$.

Wang et al. demonstrated that early-stage cervical cancer patients with fewer than 10 removed pelvic lymph nodes had worse progression-free and cancer-specific survival ${ }^{6}$. Lymph node metastasis is one of the main factors to determine the choice of treatment for patients, whether biopsy-proven or detected by preoperative imaging modalities. The European Society of Gynaecological Oncology (ESGO) guidelines recommend radical surgery in the presence of lymph node metastases.

In light of this knowledge, this retrospective study aimed to define the postoperative clinico-pathologic factors affecting lymph node metastases in cervical cancer patients.

\section{Material and Methods}

This retrospective cohort study was carried out in the Baskent University School of Medicine in Ankara, Turkey. Cervical cancer patients operated on in the gynecologic oncology clinic between 2008 and 2019 were retrospectively evaluated and the patients' demographic characteristics, pathology reports (histology, lymphovascular space invasion [LVSI], stromal invasion, parametrial involvement, lymph node metastases) were documented. This study was approved by the Baskent University Institutional Review Board.

During the study period, 55 patients who received neo-adjuvant chemotherapy and 28 patients who were treated with curative chemoradiotherapy were excluded. Patients with incomplete data and with synchronous malignancies were also excluded.

A total of 352 patients were included in the study. All patients underwent radical hysterectomy (type C) and pelvic and paraaortic lymphadenectomy. The definition of lymphadenectomy was excision of at least 10 pelvic lymph nodes from each side and excision of at least 5 paraaortic nodes.

All pathology specimens were evaluated by an expert gynecopathologist.

LVSI was defined as a tumor nest within a lymphatic or vascular space.

The depth of deep stromal invasion (DSI) was measured from the basement and was defined as invasion of more than $50 \%$ of the cervical stroma.
Parametrial and vaginal invasion was defined as tumor cells in or beyond parametrial and vaginal tissues and was determined by microscopic evaluation even in the case of smooth margins.

The follow-up protocol included gynecological examination every 3 months, vaginal cuff smear every 6 months, and computed tomography annually in the first two years (could be done earlier if clinically indicated).

Adjuvant treatment policies were determined by the multidisciplinary tumor board according to the international guidelines of relevant societies. The most important factors regarding adjuvant treatment were lymph node metastases and surgical margin status. Overall survival (OS) was defined as the time interval between surgery and death or last follow-up.

\section{Statistical Analyses}

SPSS software version 23.0 (IBM Corp., Armonk, NY, USA) was used for statistical analyses. Continuous variables were given as medians and ranges; binary variables were given as counts and percentages. Survival curves were generated using Kaplan-Meier plots, and the log-rank test was used for survival comparisons.

Univariate analyses were done using Pearson's chisquare test, Fisher's exact test, and the Mann-Whitney $\mathrm{U}$ test. Significant factors in univariant analyses were subjected to the Cox proportional hazards regression model to get hazard ratios (HRs) and 95\% confidence intervals (CIs). All $\mathrm{p}$ values were taken as significant below the value of 0.05 .

\section{Results}

A total of 352 cervical cancer patients clinically appropriate for surgery were evaluated. The median age of the study group was $49(23-87)$ years and the median tumor size was $3.2(1-11) \mathrm{cm}$. While $273(70 \%)$ patients had positive LVSI, 299 (85\%) patients had DSI of more than $50 \%$ of the cervical stroma. All patients underwent radical hysterectomy plus pelvic and paraaortic lymphadenectomy; the median number of resected lymph nodes was 36 (14-87). Ninety-seven (21\%) patients had parametrial invasion while 44 (12\%) patients had vaginal involvement.

While 216 (61.4\%) patients did not have lymph node metastases, 97 (27.8\%) patients had pelvic lymph node metastases, 34 patients had pelvic plus paraaortic lymph node invasion, and 4 (1.1\%) patients had 
isolated paraaortic lymph node metastases (Table 1). According to the 2018 FIGO staging system, 135 (37.4\%) patients were found to be stage IIIc (97 IIIc1 and 38 IIIc2), while 281 (79.7\%) patients had squamous cell histology. FIGO stages, histology, and adjuvant treatments are given in Table 1.

In univariant analyses DSI was found to affect lymph node metastases $(p=0.006)$. Additionally, LVSI and parametrial involvement significantly increased lymph node metastases $(\mathrm{p}=0.000$ and $\mathrm{p}=0.000$, respectively) (Table 2).

Vaginal and ovarian invasion did not affect lymph node metastases, and age of $>50$ years and histology also did not alter the lymph node metastasis findings ( $\mathrm{p}=0.14, \mathrm{p}=0.15, \mathrm{p}=0.58$, and 0.45 , respectively) in cervical cancer patients.

In multivariant analyses, LVSI (HR: 32.6 (95\% CI: 7.8-136.2, $\mathrm{p}=0.001$ ) and parametrial invasion (HR: 3.52, 95\% CI: $1.7-6.9, \mathrm{p}=0.001$ ) were found to be independent risk factors for lymph node metastases in cervical cancer patients (Table 2).

In Kaplan-Meir survival analyses, the log rank test showed the 5-year OS of patients with lymph node metastases to be $70 \%$ while that of patients without lymph node metastases was $85 \%$. This difference was statistically significant $(\mathrm{p}=0.001)$ (Figure 1$)$.

\section{Discussion}

We have found that LVSI and microscopic parametrial invasion independently increase the risk of lymph node metastases in cervical cancer patients while DSI, vaginal involvement, and ovarian metastases do not. Interestingly, we could not demonstrate an effect of tumor size in lymph node metastases. This may be due to the relatively large median tumor size $(3.2 \mathrm{~cm})$ and high number of cases of positive LVSI and DSI in our cohort.

Former research showed a positive correlation between LVSI and lymph node metastases of up to $32 \%$ in cervical carcinoma ${ }^{7-9}$. In the current study, we demonstrated that positive LVSI increased the risk of lymph node metastases 32-fold independently of age, DSI, and tumor size.

Positive LVSI is considered as an intermediate risk factor with tumor size and stromal invasion for earlystage cervical carcinoma ${ }^{10}$. The adjuvant treatment policy after radical surgery is mainly based on these
Table 1. Clinico-pathologic characteristics of patients

\begin{tabular}{|c|c|c|}
\hline & Number & Percentage (\%) \\
\hline \multicolumn{3}{|l|}{ LVSI } \\
\hline Positive & 273 & 70 \\
\hline Negative & 79 & 30 \\
\hline Median age & $49(23-87)$ & \\
\hline \multicolumn{3}{|l|}{ Deep stromal invasion } \\
\hline Positive & 299 & 85 \\
\hline Negative & 53 & 15 \\
\hline Median tumor size & $3.2 \mathrm{~cm}(1-11)$ & \\
\hline Parametrial involvement & 97 & 21 \\
\hline Vaginal invasion & 44 & 12 \\
\hline Median number of resected LN & $36(14-87)$ & \\
\hline Positive pelvic LN & 103 & 28 \\
\hline Positive paraaortic LN & 31 & 8 \\
\hline Isolated paraortic metastases & 4 & 1.1 \\
\hline \multicolumn{3}{|l|}{ Figo 2018 stage } \\
\hline $1 \mathrm{~B} 1$ & 28 & 8 \\
\hline 1B2 & 98 & 27.8 \\
\hline $1 \mathrm{~B} 3$ & 68 & 19.3 \\
\hline $2 \mathrm{~A} 1$ & 15 & 4.3 \\
\hline $2 \mathrm{~A} 2$ & 8 & 2.3 \\
\hline $3 \mathrm{C} 1$ & 97 & 27.6 \\
\hline $3 \mathrm{C} 2$ & 38 & 10.8 \\
\hline Ovarian metastases & 4 & 1.1 \\
\hline \multicolumn{3}{|l|}{ Adjuvant treatment } \\
\hline No adjuvant treatment & 115 & 32 \\
\hline Radiotherapy & 66 & 18 \\
\hline Chemo-radiotherapy & 140 & 5 \\
\hline Chemotherapy & 18 & 40 \\
\hline \multicolumn{3}{|l|}{ Histology } \\
\hline Squamous cell & 281 & 79.7 \\
\hline Adeno cancer & 38 & 10.8 \\
\hline Adenosquamous & 33 & 9.4 \\
\hline Total & 352 & \\
\hline
\end{tabular}

LVSI, Iympho-vascular space invasion; DSI, deep stromal invasion; LN, Iymph node.

Table 2. Univariant and multivariant analyses of factors affecting lymph node metastases

\begin{tabular}{|c|c|c|c|c|}
\hline \multirow[b]{2}{*}{ Factor } & \multirow{2}{*}{$\begin{array}{c}\text { Univariant } \\
\text { analyses P } \\
\text { value }\end{array}$} & \multicolumn{3}{|c|}{ Multivariant analyses } \\
\hline & & HR & $\begin{array}{l}95 \% \text { C. I. } \\
\text { lower-upper }\end{array}$ & $P$ value \\
\hline LVSI & 0.000 & 32.6 & $7.8-136.2$ & 0.001 \\
\hline Parametrial invasion & 0.000 & 3.52 & $1.7-6.9$ & 0.001 \\
\hline DSI & 0.006 & 0.9 & $0.57-2.9$ & 0.54 \\
\hline Tumor size & 0.1 & & & \\
\hline Age $<50$ years & 0.58 & & & \\
\hline Histology & 0.45 & & & \\
\hline Ovarian metastases & 0.15 & & & \\
\hline Vaginal invasion & 0.4 & & & \\
\hline
\end{tabular}
invasion; LN, lymph node. 


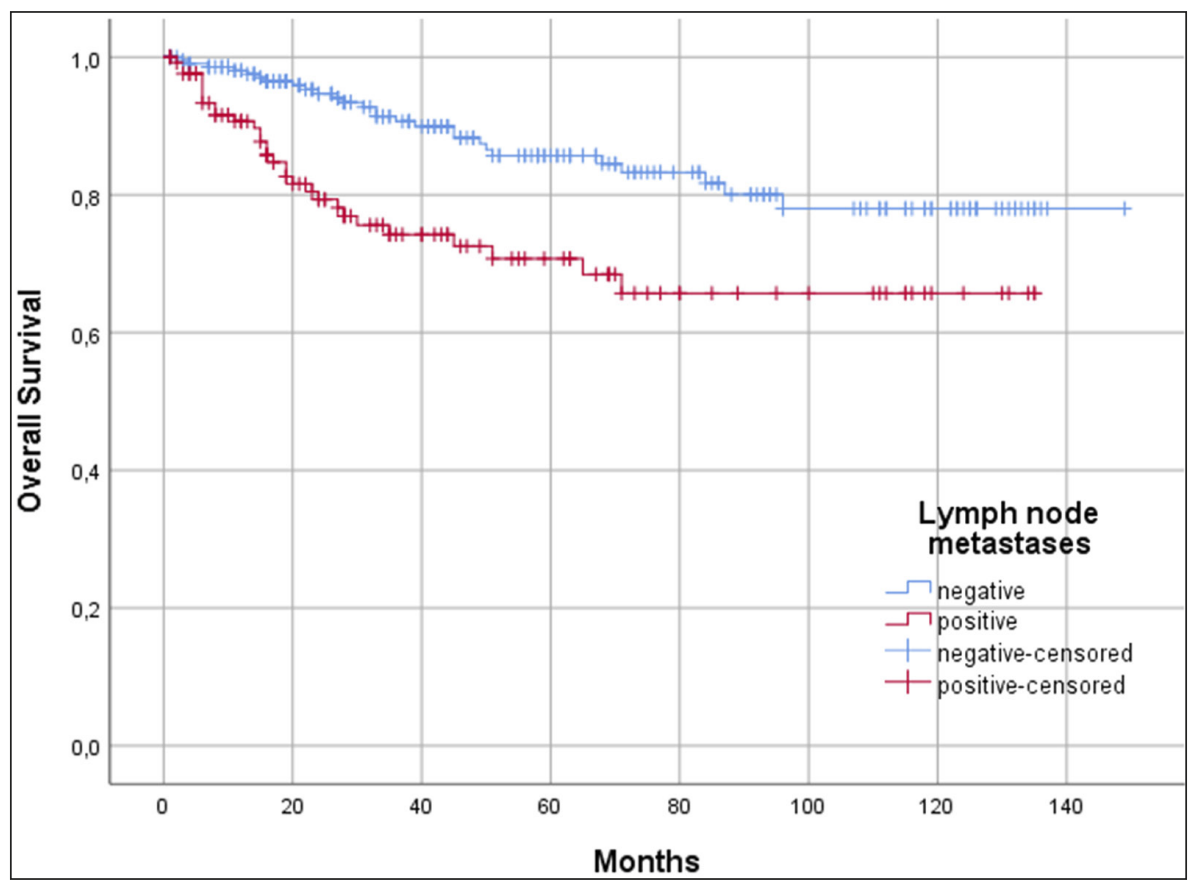

Figure 1. Overall survival of patients according to lymph node metastases $(p=0.001)$.

pathologic risk factors ${ }^{11}$. The prognostic significance of LVSI is debatable; some studies showed that it is a negative prognostic factor ${ }^{12}$, while some did not point out this relationship ${ }^{13,14}$. A recent study from our clinic demonstrated that postoperative adjuvant treatment based on intermediate risk factors did not alter progression-free survival or OS in early-stage cervical cancer patients ${ }^{15}$.

Liu et al. evaluated the factors affecting lymph node metastases in IA-IIB cervical cancer patients and found that LVSI, depth of invasion, and parametrial invasion were independent risk factors for lymph node metastases $^{16}$. Unlike that study, in our multivariant analyses we did not find DSI as an independent risk factor for lymph node metastases.

A large retrospective study from Thailand reported that parametrial invasion and DSI were independent risk factors for lymph node metastases in early-stage cervical cancer. Moreover, LVSI was found significant in univariant analyses, but it did not affect lymph node involvement in multivariant analyses ${ }^{17}$. In contrast to that study, we found DSI to be insignificant after multivariant analyses; the main factors in this contradiction are the very low rate of LVSI $(24.8 \%)$ and lymph node metastases $(4.6 \%)$ in the earlier study compared to ours ( $70 \%$ and $27.8 \%$, respectively).
Parametrial involvement entails the direct invasion of tumor cells into the connective tissue surrounding the uterine cervix and parametrial invasion is one of the most important prognostic factors in cervical cancer ${ }^{18,19}$. Standard care for patients with parametrial involvement is concurrent chemo-radiotherapy according to European guidelines ${ }^{20}$. However, radical hysterectomy with or without subsequent adjuvant treatment is another option ${ }^{21-23}$. Kasmatsu et al. evaluated 139 FIGO IIB cervical cancer patients who had undergone radical hysterectomy plus pelvic paraaortic lymph node dissection and found that $50 \%$ of these patients had pathologic parametrial invasion. In this study, lymph node metastases and parametrial involvement were found to be negative prognostic factors. Moreover, the authors demonstrated that this unique group of patients had the same oncologic results as the standard chemo-radiation group ${ }^{21}$. In our center, we operated only selected patients with parametrial involvement, and the pathologic parametrial invasion rate was $21 \%$ in the entire cohort. In addition, pathologic parametrial invasion increased the risk of lymph node metastases by nearly 3.5 -fold.

Lymph node metastasis is an independent parameter for the survival of cervical cancer patients and it decreases both OS and disease-free survival ${ }^{18}$. In our 
cohort, the 5-year OS rates of patients with and without lymph node metastases was $85 \%$ and $70 \%$, respectively $(\mathrm{p}=0.001)$.

Nowadays, instead of systemic lymphadenectomy, sentinel lymph node concept is rising in the field of gynecological cancers like other malignancies. However use of sentinel lymph node biopsy in cervical cancer has some limitations; first of all there is no prospective proof about safety of this concept, secondly; there is no standart protocol for pathologic evaluation and lastly the risk of micrometastases in non-sentinel nodes is not known ${ }^{24}$. As a result we should wait results of randomized-controlled trials.

The current study has some limitations. First of all, its retrospective design could have permitted selection bias. Secondly, our data do not include preoperative imaging to compare the results with the postoperative findings.

Our findings indicate that if a patient has positive LVSI in biopsy or cone material, it should be kept in mind that the risk of lymph node metastases cannot be underestimated. Moreover, patients with microscopic parametrial invasion are at risk of lymph node metastases. Prospective studies are needed to identify these risk factors preoperatively.

\section{References}

1. Arbyn M, Weiderpass E, Bruni L, de Sanjosé S, Saraiya M, Ferlay J, Bray F. Estimates of incidence and mortality of cervical cancer in 2018: a worldwide analysis. Lancet Glob Health 2020;8: e191-e203.

2. Koh WJ, Greer BE, Abu-Rustum NR, Apte SM, Campos SM, Chan J, et al. Cervical cancer. J Natl Compr Canc Netw 2013;11:320-43.

3. Bhatla N, Berek JS, Cuello Fredes M, Denny LA, Grenman S, Karunaratne K, et al. Revised FIGO staging for carcinoma of the cervix uteri. Int J Gynaecol Obstet 2019;145:129-35.

4. Matsuo K, Machida H, Mandelbaum RS, Konishi I, Mikami M. Validation of the 2018 FIGO cervical cancer staging system. Gynecol Oncol 2019;152:87-93.

5. Ayhan A, Aslan K, Bulut AN, Akilli H, Öz M, Haberal A, Meydanli MM. Is the revised 2018 FIGO staging system for cervical cancer more prognostic than the 2009 FIGO staging system for women previously staged as IB disease? Eur J Obstet Gynecol Reprod Biol 2019;240:209-14.

6. Wang R, Tao X, Wu X, Jiang H, Xia H. Number of Removed Pelvic Lymph Nodes as a Prognostic Marker in FIGO Stage IB1 Cervical Cancer with Negative Lymph Nodes. J Minim Invasive Gynecol 2020;27:946-52.
7. Baalbergen A, Ewing-Graham PC, Hop WC, Struijk P, Helmerhorst TJ. Prognostic factors in adenocarcinoma of the uterine cervix. Gynecologic oncology 2004;92:262-7.

8. Morice P, Piovesan P, Rey A, Atallah D, Haie-Meder C, Pautier $\mathrm{P}$, et al. Prognostic value of lymphovascular space invasion determined with hematoxylin-eosin staining in early stage cervical carcinoma: results of a multivariate analysis. Ann Oncol 2003;14:1511-7.

9. Milam MR, Frumovitz M, dos Reis R, Broaddus RR, Bassett RL, Jr., Ramirez PT. Preoperative lymph-vascular space invasion is associated with nodal metastases in women with early-stage cervical cancer. Gynecologic oncology 2007;106:12-5.

10. Sedlis A, Bundy BN, Rotman MZ, Lentz SS, Muderspach LI, Zaino RJ. A randomized trial of pelvic radiation therapy versus no further therapy in selected patients with stage IB carcinoma of the cervix after radical hysterectomy and pelvic lymphadenectomy: A Gynecologic Oncology Group Study. Gynecol Oncol 1999;73:177-83.

11. Chernofsky MR, Felix JC, Muderspach LI, Morrow CP, Ye W, Groshen SG, Roman LD. Influence of quantity of lymph vascular space invasion on time to recurrence in women with early-stage squamous cancer of the cervix. Gynecologic oncology 2006;100:288-93.

12. Singh P, Tripcony L, Nicklin J. Analysis of prognostic variables, development of predictive models, and stratification of risk groups in surgically treated FIGO early-stage (IA-IIA) carcinoma cervix. International journal of gynecological cancer: official journal of the International Gynecological Cancer Society 2012;22:115-22.

13. Yan M, Zhang YN, He JH, Sun JR, Sun XM. Influence of lymph vascular space invasion on prognosis of patients with early-stage cervical squamous cell carcinoma. Chin J Cancer 2010;29:42530.

14. Creasman WT, Kohler MF. Is lymph vascular space involvement an independent prognostic factor in early cervical cancer? Gynecologic oncology 2004;92:525-9.

15. Akilli H, Tohma YA, Bulut AN, Karakas LA, Haberal AN, Kuscu UE, Ayhan A. Comparison of no adjuvant treatment and radiotherapy in early-stage cervical carcinoma with intermediate risk factors. International journal of gynaecology and obstetrics: the official organ of the International Federation of Gynaecology and Obstetrics 2020;149:298-302.

16. Liu Y, Zhao LJ, Li MZ, Li MX, Wang JL, Wei LH. The Number of Positive Pelvic Lymph Nodes and Multiple Groups of Pelvic Lymph Node Metastasis Influence Prognosis in Stage IA-IIB Cervical Squamous Cell Carcinoma. Chin Med J (Engl)2015;128:2084-9.

17. Nanthamongkolkul K, Hanprasertpong J. Predictive Factors of Pelvic Lymph Node Metastasis in Early-Stage Cervical Cancer. Oncol Res Treat 2018;41:194-8.

18. Xia X, Xu H, Wang Z, Liu R, Hu T, Li S. Analysis of Prognostic Factors Affecting the Outcome of Stage IB-IIB Cervical Cancer Treated by Radical Hysterectomy and Pelvic Lymphadenectomy. American Journal of Clinical Oncology 2016;39:604-8. 
19. Takeda N, Sakuragi N, Takeda M, Okamoto K, Kuwabara $\mathrm{M}$, Negishi $\mathrm{H}$, et al. Multivariate analysis of histopathologic prognostic factors for invasive cervical cancer treated with radical hysterectomy and systematic retroperitoneal lymphadenectomy. Acta Obstetricia et Gynecologica Scandinavica 2002;81:1144-51.

20. Marth C, Landoni F, Mahner S, McCormack M, GonzalezMartin A, , et al. Cervical cancer: ESMO Clinical Practice Guidelines for diagnosis, treatment and follow-up. Ann Oncol 2017;28: iv72-iv83. Erratum in: Ann Oncol 2018;29(Suppl 4): iv262. Erratum in: Ann Oncol 2018;29(Suppl 4): iv262.

21. Kasamatsu T, Onda T, Sawada M, Kato T, Ikeda S. Radical hysterectomy for FIGO stage IIB cervical cancer: clinicopathological characteristics and prognostic evaluation. Gynecologic Oncology 2009;114:69-74.
22. Suprasert P, Srisomboon J, Charoenkwan K, Siriaungul S, Khunamornpong $S$, Siriaree $S$, et al. Outcomes of abandoned radical hysterectomy in patients with stages IB-IIA cervical cancer found to have positive nodes during the operation. International journal of gynecological cancer: official journal of the International Gynecological Cancer Society 2005;15:498502.

23. Yuan L, Guo J, Zhang X, Chen M, Xu C, Yao L. Feasibility of radical hysterectomy in women with FIGO stage IIB cervical cancer: an observation study of 10-year experience in a tertiary center. Onco Targets Ther 2018;11:5527-33.

24. Cibula D, McCluggage WG. Sentinel lymph node (SLN) concept in cervical cancer: Current limitations and unanswered questions. Gynecol Oncol 2019;152:202-7. 